\title{
Zavádzanie trestnej zodpovednosti za zneužívanie finančného trhu*
}

\author{
Imposition of Criminal Liability for Market Abuse
}

\author{
Jozef Záhora ${ }^{* *}$
}

\begin{abstract}
Abstrakt

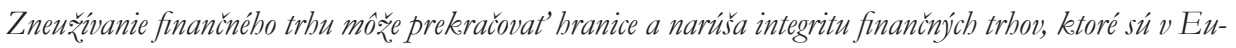
rópskej únii stále viac integrované. Manipulácia s významnými referenćnými hodnotami alebo pokus o ňu môže mat' vážny vplyv na dôveru trbu a mobla by viest' ke významným stratám pre investorov a ke narušeniam reálnej ekonomiky. Z toho dôvodu je dôlě̌ité, aby sa prijali v̌̌etky nevyhnutné kroky s cielom predíst' takejto manipulácii a umo:̌nit prislušným orgánom ukladanie sankcií. Autor predstavije nedávne legislativne opatrenia v tejto oblasti v Európskej únii. Cielom týchto opatrení je zuýsít' dôveru investorov a integritu trbu, a to tým, že sa osobám, ktoré majú dôverné informácie, zakáą̌ze obchodovat' so súvisiacimi finančnými nástrojmi, a že sa zakáǎ̌e manipulácia s trbmi prostredníctvom postupov, ako sú sírenie nepravdivých informácii alebo neoverených správ a uskutočnovanie obchodov, ktoré zarucuuju ceny na neprirodzenej úrovni.
\end{abstract}

\section{Klíčová slova}

Zneu民̌ivanie trbu; finančné nástroje; obchodovanie s vyư̌itím dôverných informácii; neoprávnené zverejnovanie dôverných informácií; trestné sankcie; trestná zodpovednost' právnickeých osôb.

\section{Abstract}

Market abuse can occur across borders and harms the integrity of financial markets which are increasingly integrated in the European union. Any actual or attempted manipulation of important benchmarks can have a serious impact on market confidence and could result in significant losses for investors and distortions of the real economy. It is also essential that all necessary steps are taken to prevent such manipulation and to enable and facilitate the competent authorities in imposing sanctions. The author presents recent legislative action in this field in the European Union. The aim of these measures is to increase investors 'confidence and market integrity by probibiting those who possess inside information from trading in related financial instruments, and by probibiting the manipulation of markets through practices such as spreading false information or rumours and conducting trades which secure prices at abnormal levels.

\section{Keywords}

Market Abuse; Financial Instruments; Insider Dealing; Unlanful Disclosure of Inside Information; Criminal Sanctions; Liability of Legal Person.

* Táto práca bola podporovaná Agentúrou na podporu výskumu a vývoja na základe Zmluvy č. APVV0356-12/ This work was supported by the Slovak Research and Development Agency under the contract No. APVV-0356-12.

* Prof. JUDr. Jozef Záhora, PhD., Fakulta práva, Paneurópska vysoká škola, Bratislava, Slovenská republika / Faculty of Law, Paneuropean University, Bratislava, Slovak Republic / E-mail:jozef.zahora@paneurouni.com 


\section{Úvod}

Efektívny finančný trh a väčšia dôvera investorov si vyžaduje integritu trhu s cennými papiermi. Hladké fungovanie trhov s cennými papiermi a dôvera verejnosti v trhy sú nevyhnutnou podmienkou hospodárskeho rastu a vytváranie pracovných miest a dostatku životných potrieb. Zneužívanie finančného trhu poškodzuje integritu finančných trhov a dôveru verejnosti v cenné papiere, deriváty a referenčné hodnoty.

Počas posledných rokov sa môžeme stretnút' s názormi, že riadenie obchodných spoločností je zamerané predovšetkým na efektívnost' finančných trhov, stabilitu a transparentnost'. V skutočnosti to má za následok liberalizáciu, ktorá vytvorila celospoločenský konsenzus o potrebe dat' obchodným spoločnostiam väčšiu slobodu podnikat'. Podl’a týchto názorov, táto sloboda prináša väčšiu autonómiu efektivitu, zisk a zvyšovania blaha. ${ }^{1}$ V dôsledku vývoja regulácie, trhu a technológií sa objavili nedostatky v regulácii nových trhov, platforiem a mimoburzových nástrojov, niekedy označované aj ako zneužívanie trhu. Zneužívanie trhu je pojem, ktorý zahŕňa neoprávnené konanie na finančných trhoch a mal by sa chápat' tak, že pozostáva z obchodovania s využitím dôverných informácií, neoprávneného zverejňovania dôverných informácií a manipulácie s trhom. Takéto konanie bráni úplnej a riadnej transparentnosti trhu, ktorá je predpokladom pre obchodovanie všetkých hospodárskych subjektov na integrovaných finančných trhoch. ${ }^{2}$ Hoci môže byt' pre príslušný orgán t’ažké alebo nemožné preukázat', že manipulácia s referenčnou hodnotou mala vplyv na cenu súvisiacich finančných nástrojov, akákol’vek skutočná manipulácia s významnými referenčnými hodnotami alebo pokus o ňu môže mat' vážny vplyv na dôveru trhu a mohla by viest' $\mathrm{k}$ významným stratám pre investorov a k narušeniam reálnej ekonomiky, a to vzhl'adom na rozšírené používanie referenčných indexov ako referenčných sadzieb, napr. pre úrokové swapy a hypotéky s premenlivou úrokovou sadzbou. ${ }^{3}$

\section{Historický exkurz}

Hoci v rámci Európskych spoločenstiev zneužívanie finančného trhu bolo zakázané od vytvorenia jedného trhu v roku 1992, ${ }^{4}$ v bývalom Československu v ,predrevolučnom

1 Porovnaj TARDIVO, G., S. BRESCIANI a F. FABRIS. Internal Dealing and Insider Trading: Focus on Financial Market Discipline in Italy Empirical Research Findings. Journal of Financial Management \& Analysis, Jan, 2011, vol. 24, no. 1, s. 24.

2 Bližšie recital 7 Nariadenia Európskeho parlamentu a Rady (EÚ) č. 596/2014 zo 16. apríla 2014 o zneužívaní trhu (nariadenie o zneužívaní trhu) a o zrušení smernice Európskeho parlamentu a Rady 2003/6/ES a smerníc Komisie 2003/124/ES, 2003/125/ES a 2004/72/ES, U. v. EÚ L 173, 12. 6. 2014, s. 1-61.

3 Bližšie Zmenený a doplnený návrh SMERNICA EURÓPSKEHO PARLAMENTU A RADY o trestných sankciách za obchodovanie s využitím dôverných informácií a manipuláciu s trhom (predložený v súlade s článkom 293 ods. 2 ZFEÚ) /* COM/2012/0420 final - 2011/0297 (COD) */, s. 2.

4 Bližšie WARREN, M. G. The Regulation Of Insider Trading In The European Community. Washington \& Lee Law Revue, No. 3/1991, s. 1037. 
období“, pred rokom 1989 nebola spoločenská potreba sankcionovat' zneužívanie finančného trhu. Súkromné vlastníctvo sa umožňovalo len v obmedzenom rozsahu a všetky obchodné spoločnosti boli v štátnom vlastníctve.

V súvislosti s transformáciou ekonomiky z centrálne riadnej na trhovú ekonomiku a so zmenami právneho poriadku, najmä v oblasti ekonomických vzt'ahov a tiež ako reakcia na negatívne javy, ktoré sa v ekonomike začali vyskytovat', bol s účinnost'ou 1. januárom 1992 do Trestného zákona č. 140/1961 Zb. v znení neskorších predpisov doplnený trestný čin podl'a \128 Zneužívanie informácií v obchodnom styku. ${ }^{5}$

Ustanovenie pozostávalo z dvoch samostatných skutkových podstát:

a) tzv. insider trading (\$ 128 ods. 1 Trestnébo zákona č. 140/1961 Zb.) ktorého sa dopustí ten kto v úmysle zadovážit' sebe alebo inému výhodu alebo prospech neoprávnene použije informáciu dosial' nie verejne prístupnú, ktorú získal z dôvodu svojho zamestnania, povolania, postavenia alebo svojej funkcie a ktorej zverejnenie podstatne ovplyvňuje rozhodovanie v obchodnom styku, a uskutoční alebo dá podnet na uskutočnenie zmluvy alebo operácie na organizovanom trhu cenných papierov alebo tovaru,

b) tzv. selftrading (\ 128 ods. 2 Trestnébo zákona č. 140/1961 Zb.) ktorého sa dopustí ten kto ako pracovník, člen orgánu, spoločník, podnikatel' alebo účastník na podnikaní dvoch alebo viacerých podnikov alebo organizácií s rovnakým alebo podobným predmetom činnosti $\mathrm{v}$ úmysle uvedenom v odseku 1 uzavrie alebo dá popud na uzavretie zmluvy na úkor jednej alebo viacerých z nich. ${ }^{6}$

Podl'a dôvodovej správy ${ }^{7}$ podkladom na zaradenie tohto trestného činu bolo, že v apríli 1989 bol účastníckym štátom Rady Európy predložený návrh Dohody o tzv. „Insider trading", teda o obchodných a finančných operáciách, uskutočňovaných „zvnútra“, v dôsledku prístupu k informáciám, ktoré má dotyčná osoba, uskutočňujúca transakciu, $\mathrm{k}$ dispozícii vd'aka svojmu postavení v rámci podniku, v dôsledku postavenia na burze a pod. Podstatou konania je zneužívanie privilegovaných informácií, ktoré niekto získa z titulu svojho postavenia. Je zaujímavé, že Slovenská republika doposial uvedený dohovor neratifikovala, Česká republika tak urobila po cca 8 rokoch. ${ }^{9}$

Zákonodarca pri zavádzaní uvedených trestných činov do Trestného zákona z roku 1961 v tej dobe mal na mysli predovšetkým ochranu štátnych podnikov pred konkurenčným konaním zo strany manažmentu podniku. Konkrétne prípady sú popísané v odbornej literatúre, napr. riaditel' štátnej spoločnosti si založil súkromnú spoločnost' s rovnakým

5 Zákon č. 557/1991 Zb. ktorým sa mení a dopĺňa Trestný zákon.

6 Porovnaj ŠÁMAL, P. et al. Trestní zákoník II. \140 až 421. Komentár. 2. vyd. Praha: C. H. Beck, 2012, s. 2604.

7 Dôvodová správa k zákonu č. 557/1991 Zb., ktorým sa mení a dopĺn̆a Trestný zákon.

8 Convention on Insider Trading, ETS No. 130.

9 Sdělení Ministerstva zahraničních věcí 142/2000 S. m. s. o přijetí Úmluvy o finančních operacích prováděných důvěrně obeznámenými osobami, Sdělení Ministerstva zahraničních věcí 143/2000 S. m. s. o přijetí Protokolu k Úmluvě o finančních operacích prováděných důvěrně obeznámenými osobami. 
predmetom činnosti a ako riaditel' štátne spoločnosti predal jeho súkromnej spoločnosti komoditu (papier) o ktorom vedel, že v najbližšom období bude papier vyňatý spod cenovej regulácie. Bez toho aby tovar opustil sklady štátneho podniku o niekol'ko mesiacov tento papier predal naspät’ štátnemu podniku, ale za cenu o 50 \% vyššiu. ${ }^{10}$

Právna úprava uvedeného trestného činu nebola zásadne novelizovaná. V Českej republike sa rozvinula vel'ká debata v súvislosti návrhom trestného zákonníka v roku 2006, kedy pri prerokovávaní návrhu v Poslaneckej snemovne, z poslaneckej iniciatívy bolo navrhnuté vypustenie ods. 2 tzv. ,,selftrading“. Tento návrh bol následne ústavno-právnym výborom, tak aj Poslaneckou snemovňou v tret’om čítaní prijatý. Prijatá zmena sa stala „hlavným dôvodom“ pre neschválenie návrhu trestného zákonníka v Poslanecké snemovni po jeho odmietnutie Senátom Parlamentu České republiky. ${ }^{11}$ Niektorí autori tento pokus nazvali ako poslanecká , detunelážc. $\cdot{ }^{12}$

$\mathrm{V}$ rámci rekodifikácie $\mathrm{v}$ Slovenskej republike prešlo uvedené ustanovenie niekol’kými zmenami. Zo základnej skutkovej podstaty tzv. insidertradingu v ods. 1 bol vypustený motív „v úmysle zadovážit’ sebe alebo inému výhodu alebo prospech“. Ostatné zmeny boli skôr technického alebo formulačného charakteru. V odseku 2, ktorý postihoval tzv. selftrading boli vykonané len technické zmeny a formulačné. Až do súčasnosti jedinou relevantnú novelou Trestného zákona, ktorá menila uvedené ustanovenie bola novela ${ }^{13}$ s účinnost'ou od 1. 1. 2017, ktorá trestnost' tohto činu doplnila aj o neoprávnené použitie dôvernej informácie podl'a osobitného predpisu alebo vyzradenie takejto dôvernej informáciu nepovolanej osobe a horná hranica trestnej sadzby v základnej skutkovej podstate sa zvýšila z troch na štyri roky.

Okrem tejto zmeny, citovaná novela doplnila do Trestného zákona aj nový trestný čin a to Manipulácia s trhom (\265a Trestného zákona) ako transpozíciu Smernica o zneužívaní trhu. ${ }^{14}$

\section{Ochrana pred zneužívaním finančného trhu v práve Európskej únie}

Ako už bolo uvedené, s vytvorením jednotného európskeho trhu bolo vytvorená aj regulácia tzv. insider dealing. ${ }^{15} \mathrm{~V}$ roku 2003 boli uvedené regulačné mechanizmy nahradené

10 Porovnaj napr. DOLENSKÝ, A. Novelizace trestního zákona 1991. Bulletin advokacie, 1992, č. 1, s. 9; HERCZEG, J. Trestní postih zneužívání postavení v obchodním styku. Trestněprávní revue, 12/2006, s. 361.

11 Bližšie ŠÁMAL, P. Aktuální otázky a judikatura k trestnému činu zneužívání informací v obchodním styku. Bulletin advokacie, č. 1-2/2008, s. 17.

12 HERCZEG, J. Trestní postih zneužívání postavení v obchodním styku. Trestněprávní revue, 12/2006, s. 361.

13 Zákon č. 316/2016 Z. z. o uznávaní a výkone majetkového rozhodnutia vydaného v trestnom konaní v Európskej únii a o zmene a doplnení niektorých zákonov.

14 Smernica Európskeho parlamentu a Rady 2014/57/EÚ zo 16. apríla 2014 o trestných sankciách za zneužívanie trhu (smernica o zneužívaní trhu), Ú. v. EÚ L 173, 12. 6. 2014, s. 179-189.

15 Council Directive 89/592/EEC of 13 November 1989 coordinating regulations on insider dealing, Ú. v. ES L 334, 18. 11. 1989, s. 30-32. 
súborom nových legislatívnych nástrojov predovšetkým: Smernicou 2003/6/ES o obchodovaní s využitím dôverných informácií a o manipulácii s trhom ${ }^{16}$, Nariadením Komisie $^{17}$ ktorou sa vykonáva smernica Európskeho parlamentu a Rady 2003/6/ES, Smernicou Komisie ${ }^{18}$ 2003/124/ES ktorou sa vykonáva smernica Európskeho parlamentu a Rady 2003/6/ES, Smernicou Komisie 2003/125/ES ktorou sa vykonáva smernica Európskeho parlamentu a Rady 2003/6/ES ${ }^{19}$.

Uvedenými nástrojmi sa zaviedol súhrnný rámec pre boj proti praktikám súvisiacim s obchodovaním s využitím dôverných informácií a manipuláciou s trhom. Ciel’om smernice 2003/6/ES bolo zvýšit' dôveru investorov a integritu trhu, a to tým, že sa osobám, ktoré majú dôverné informácie, zakáže obchodovat' so súvisiacimi finančnými nástrojmi, a že sa zakáže manipulácia trhov prostredníctvom postupov, ako sú šírenie nepravdivých informácií alebo neoverených správ a uskutočňovanie obchodov, ktoré zaručujú ceny na neprirodzenej úrovni. Po niekol'kých rokoch uplatňovania smernice o zneužívaní trhu, Európska komisia posúdila uplatňovanie smernice a zistila niekol'ko problémov, ktoré majú nepriaznivý vplyv z hl'adiska integrity trhu a ochrany investorov, vedú $\mathrm{k}$ nerovnakým podmienkam a ich dôsledkom sú náklady na dodržiavanie predpisov a znížená motivácia emitentov, ktorých finančné nástroje sú prijaté na obchodovanie na rastových trhoch malých a stredných podnikov, zvýšit' kapitál.

V dôsledku vývoja regulácie, trhu a technológií sa objavili nedostatky v regulácii nových trhov, platforiem a mimoburzových nástrojov. Obdobne, tie isté faktory viedli k medzerám v regulácii komodít a súvisiacich derivátov. Skutočnost', že regulačné orgány nemajú určité informácie a právomoci a že sankcie sú bud’ nedostatočné, alebo nedostatočne odrádzajúce, znamená, že regulačné orgány nemôžu účinne presadzovat' uplatňovanie smernice. $^{20}$

Aj ked’ pravidlá na predchádzanie skutkom zneužívania trhu a boja proti nim existujú na úrovni EÚ od roku 2003, skúsenosti ukázali, že požadovaný účinok tento systém nedosiahol. Komisia dospela k záveru, že by sa uvedený systém mal nahradit’. Výsledkom

16 Smernica Európskeho parlamentu a Rady 2003/6/ES z 28. januára 2003 o obchodovaní s využitím dôverných informácí́ a o manipulácii s trhom (zneužívanie trhu), Ú. v. EÚ L 96, 12. 4. 2003, s. 16-25.

17 Nariadenie Komisie (ES) č. 2273/2003 z 22. decembra 2003, ktorou sa vykonáva smernica Európskeho parlamentu a Rady 2003/6/ES, pokial' ide o výnimky pre programy spätného výkupu a stabilizácie finančných nástrojov, Ú. v. EÚ L 336, 23. 12. 2003, s. 33-38.

18 Smernica Komisie 2003/124/ES z 22. decembra 2003, ktorou sa vykonáva smernica Európskeho parlamentu a Rady 2003/6/ES, pokial ide o vymedzenie a zverejňovanie dôverných informácií a vymedzenie manipulácie s trhom, Ú. v. EÚ L 339, 24. 12. 2003, s. 70-72.

19 Smernica Komisie 2003/125/ES z 22. decembra 2003, ktorou sa vykonáva smernica Európskeho parlamentu a Rady 2003/6/ES, pokial' ide o správne poskytovanie investičných odporúčaní a zverejňovanie konfliktu záujmov, Ú. v. EÚ L 339, 24. 12. 2003, s. 73-77.

20 Návrh nariadenia Európskeho parlamentu a Rady o obchodovaní s využitím dôverných informácií a o manipulácii s trhom (zneužívanie trhu) (COM(2011)0651, 20. 10. 2011. 
týchto postupov bolo nahradenie doterajšieho systému a prijatím nariadenia o zneužívaní trhu, ${ }^{21} \mathrm{~s}$ účinnost'ou od 3. júla 2016. Nariadenia sú právne akty, ktoré sa uplatňujú automaticky a jednotne vo všetkých krajinách Európskej únie hned’ po nadobudnutí ich účinnosti bez toho, aby museli byt' transponované do vnútroštátnych právnych predpisov. Sú záväzné v celom svojom rozsahu pre všetky krajiny Európskej únie. Sformulovanie požiadaviek týkajúcich sa zneužívania trhu vo forme nariadenia zabezpečí, že tieto požiadavky sú priamo uplatnitel'né. To by malo zabezpečit' jednotné podmienky tým, že sa zabráni rozdielnosti vnútroštátnych požiadaviek v dôsledku transpozície smernice. Toto nariadenie vyžaduje, aby sa všetky osoby riadili rovnakými pravidlami v celej Európskej únii.

Posilnenie a zaručenie koherentnosti správnych sankcií je spracované v nariadení o zneužívaní trhu. S ciel'om ustanovuje povinnost' členských štátov zabezpečit' minimálne pravidlá týkajúce sa vymedzenia najzávažnejších skutkov zneužívania trhu a minimálnych sadzieb príslušných trestných sankcií bola následne prijatá Smernica o trestných sankciách za zneužívanie trhu (smernica o zneužívaní trhu). ${ }^{22}$

\section{Smernica o zneužívaní trhu}

Právny základ smernice o zneužívaní trhu vychádza z článku 83 ods. 2 ZFEÚ. ${ }^{23}$ Toto ustanovenie obsahuj tzv. ,flexibilnú klauzulu“ umožňujúcu prijímat' legislatívne akty predstavujúce minimálnu harmonizáciu skutkových podstát v oblasti trestného práva, ktoré sú je nevyhnutné na zabezpečenie účinného uskutočňovania politiky Únie v oblasti, ktorá bola predmetom harmonizačných opatrení. Smernice môžu v tomto prípade ustanovit' minimálne pravidlá týkajúce sa vymedzenia trestných činov a sankcií v dotknutej oblasti. ${ }^{24}$

Táto smernica ustanovuje minimálne pravidlá pre trestné sankcie za obchodovanie s využitím dôverných informácií, neoprávnené zverejňovanie dôverných informácií a manipuláciu s trhom s ciel'om zabezpečit' v EÚ integritu finančných trhov a zvýšit' ochranu investorov a dôveru v tieto trhy.

Smernica obsahuje vymedzenie troch trestných činov súvisiacich so zneužívaním trhu: Obchodovanie s využitím dôverných informácií, Neoprávnené zverejňovanie dôverných informácií a Manipulácia s trhom.

21 Nariadenie Európskeho parlamentu a Rady (EÚ) č. 596/2014 zo 16. apríla 2014 o zneužívaní trhu (nariadenie o zneužívaní trhu) a o zrušení smernice Európskeho parlamentu a Rady 2003/6/ES a smerníc Komisie 2003/124/ES, 2003/125/ES a 2004/72/ES, Ú. v. EÚ L 173, 12. 6. 2014, s. 1-61.

22 Smernica Európskeho parlamentu a Rady 2014/57/EÚ zo 16. apríla 2014 o trestných sankciách za zneužívanie trhu (smernica o zneužívaní trhu), Ú. v. EÚ L 173, 12. 6. 2014, s. 179-189.

23 Zmluva o fungovaní Európskej únie (Konsolidované znenie), Ú. v. EÚ C 202, 7. 6. 2016, s. 47-199.

24 Bližšie IVOR, J., P. POLÁK a J. ZÁHORA. Trestné právo hmotné I. všeobecná čast’. Bratislava: Wolters Kluver, 2016, s. 526 a nasl. 
V článku 3 smernice sa vymedzujú znaky obchodovania s využitím dôverných informácií, ktoré by členské štáty mali považovat' za trestné činy, a preto by mali podliehat' trestným sankciám. Takýmito znakmi sú obchodovanie s využitím dôverných informácií, odporúčanie inej osobe zapojit' sa do obchodovania s využitím dôverných informácií alebo navádzanie inej osoby zapojit' sa do obchodovania s využitím dôverných informácií. Takéto konania sa za trestné činy považujú aspoň v závažných prípadoch a vtedy, ak sú spáchané úmyselne. Za obchodovanie s využitím dôverných informácií sa považuje činnost', ked' osoba má dôverné informácie a využíva ich priamo alebo nepriamo na nadobudnutie alebo prevod finančných nástrojov, na ktoré sa tieto informácie vzt'ahujú, a to na vlastný účet alebo na účet tretej osoby. Pri vymedzenie pojmu „dôverné informácie“ smernica odkazuje na definíciu uvedenú v článku 7 ods. 1 až 4 nariadenia (EÚ) č. 596/2014 o zneužívaní trhu.

Neoprávnené zverejňovanie dôverných informácií v zmysle č. 4 smernice by malo byt' postihované ako trestný čin aspoň v závažných prípadoch a vtedy, ak je spáchané úmyselne. Za neoprávnené zverejňovanie dôverných informácií považujú prípady, ked’ osoba má dôverné informácie a poskytne tieto informácie inej osobe, okrem prípadov, ked’ k zverejneniu dôjde v rámci bežného výkonu zamestnania, povolania alebo povinností. Trestne činy súvisiace s dôvernými informáciami by sa mali vzt'ahovat' na osoby, ktoré majú dôverné informácie, o ktorých vedia, že sú dôvernými informáciami. ${ }^{25}$

Podobne ako v predchádzajúcich trestných činoch, aj pri trestnom čine manipulácie s trhom sa trestná zodpovednost' má vyvodzovat' aspoň v závažných prípadoch a vtedy, ak je čin spáchaný úmyselne.

Okrem dokonaných trestných činov, členské štáty majú v zmysle č. 6 smernice ako trestný čin postihovat' aj podnecovanie, napomáhanie a navádzanie na uvedené trestné činy. Okrem trestných sankcií pre fyzické osoby, smernica stanovuje povinnost' vyvodzovat' zodpovednost' aj voči právnickým osobám za trestné činy uvedené v článkoch 3 až 6 smernice a ukladat' im za to účinné, primerané a odradzujúce sankcie.

\section{Právna úprava v Slovenskej republike}

V právnom poriadku Slovenskej republiky je trestnoprávna ochrana pred zneužívaním finančného trhu obsiahnutá $\mathrm{v}$ trestných činoch Zneužívania informácií v obchod-

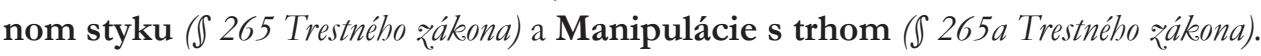

Ako už bolo uvedené, objektívna stránka trestného činu zneužívania informácií v obchodnom styku má dve formy:

- páchatel' neoprávnene použije informáciu dosial' verejne neprístupnú, ktorú získal vo svojom zamestnaní, povolaní, postavení alebo vo svojej funkcii a ktorej

25 Návrh Smernice Európskeho parlamentu a Rady o trestných sankciách za obchodovanie s využitím dôverných informácií a manipuláciu s trhom, /* KOM/2011/0654 v konečnom znení - 2011/0297 (COD) */, s. 6. 
zverejnenie podstatne ovplyvňuje rozhodovanie v obchodnom styku, a uskutoční alebo dá podnet na uskutočnenie zmluvy alebo operácie na organizovanom trhu cenných papierov alebo tovaru, alebo kto neoprávnene použije dôvernú informáciu podl'a osobitného predpisu alebo kto takú dôvernú informáciu nepovolanej osobe vyzradí (\265 ods. 1 Trestného zákona),

- zamestnanec, člen štatutárneho orgánu, spoločník, podnikatel’ alebo účastník na podnikaní dvoch alebo viacerých podnikov alebo právnických osôb s rovnakým alebo podobným predmetom činnosti v úmysle uvedenom v odseku 1 uzavrie alebo dá podnet na uzavretie zmluvy na úkor jednej alebo viacerých z nich ( $\int 265$ ods. 2 Trestného zákona).

Páchatel'om v obidvoch prípadoch môže byt' iba subjekt špeciálny. Páchatel' v zmysle \265 ods. 1 musí informáciu získat' vo svojom „Zamestnaní, povolaní, postavení alebo vo svojej funkciic resp. v prípade \265 ods. 2 ,zamestnanec, člen štatutárneho orgámu, spoločnike, podnikatel' alebo účastnik na podnikani dvoch alebo viacerých podnikov alebo právnických osôb s rounakým alebo podobným predmetom činnosti“. Páchatel'om môže byt’ aj právnická osoba ( $\left.\int 3 \mathrm{TZPO}^{26}\right)$.

Objektívnu stránku trestného činu manipulácie s trhom charakterizuje konanie páchatel'a ktorý

- neoprávnene uvedie nepravdivé alebo hrubo skresl’ujúce údaje o ponuke, dopyte alebo o cene finančného nástroja alebo súvisiacej spotovej zmluvy týkajúcej sa komodít,

- neoprávnene spôsobí dosiahnutie alebo udržanie ceny finančného nástroja alebo súvisiacej spotovej zmluvy týkajúcej sa komodít na neprirodzenej alebo umelej úrovni,

- neoprávnene manipuluje s výpočtom referenčnej hodnoty na trhu,

- použitím podvodného konania alebo machinácie uskutoční obchod, dá pokyn na uskutočnenie obchodu alebo sa dopustí iného konania ovplyvňujúceho cenu finančného nástroja alebo súvisiacej spotovej zmluvy týkajúcej sa komodít.

Páchatel'om môže byt' ktorákol’vek trestne zodpovedná fyzická osoba (subjekt všeobecný). Páchatel'om trestného činu manipulácie s trhom môže byt' aj právnická osoba ( 3 TZPO).

\section{Záver}

Trestné činy súvisiace so zneužívaním trhu našt'astie nepatria $\mathrm{v}$ podmienkach slovenskej republiky medzi frekventované trestné činy. Podl'a dostupných policajných štatistík počty zistených trestných činov za posledných 5 rokov sa pohybujú v rozmedzí od žiadneho registrovaného trestného činu (rok 2014) až po 6 registrovaných trestných činov (rok 2012 a 2015). Za celé sledované obdobie bola konkrétna osoba obvinená iba

26 Zákon č. 91/2016 Z. z. o trestnej zodpovednosti právnických osôb a o zmene a doplnení niektorých zákonov. 
v troch prípadoch (rok 2013 - 1 osoba, rok 2015 - 2 osoby). Škoda sa pohybuje v rozmedzí od 62 tis. EUR (2013) až po 4333 tis. EUR (2015). T policajných štatistík vyplýva, že všetky prípady sa týkali iba \265 ods. 1 Trestného zákona, tzv. „,insider trading“, prípad tzv. „selftrading“ (\$ 265 ods. 2 Trestného zákona) nebol v sledovanom období zistený.

V Českej republike sa v sledovanom období počet registrovaných trestných činov „Zneǔ̌ití informace a postavení v obchodnim styku" pohyboval v rozmedzí od 22 (rok 2015) až po 45 (rok 2012). Počet zistených páchatel'ov je podstatne vyšší ako v Slovenskej republike, celkom za 5 rokov je to 53 a v jednotlivých rokoch sa tento počet pohyboval od 5 (rok 2015) až po 20 (rok 2014). Spôsobené škody sa pohybovali v rozmedzí od 32333 tis. CZK (1 197 tis. EUR) v roku 2015, po 140499 tis. CZK (5200 tis. EUR) v roku 2012.

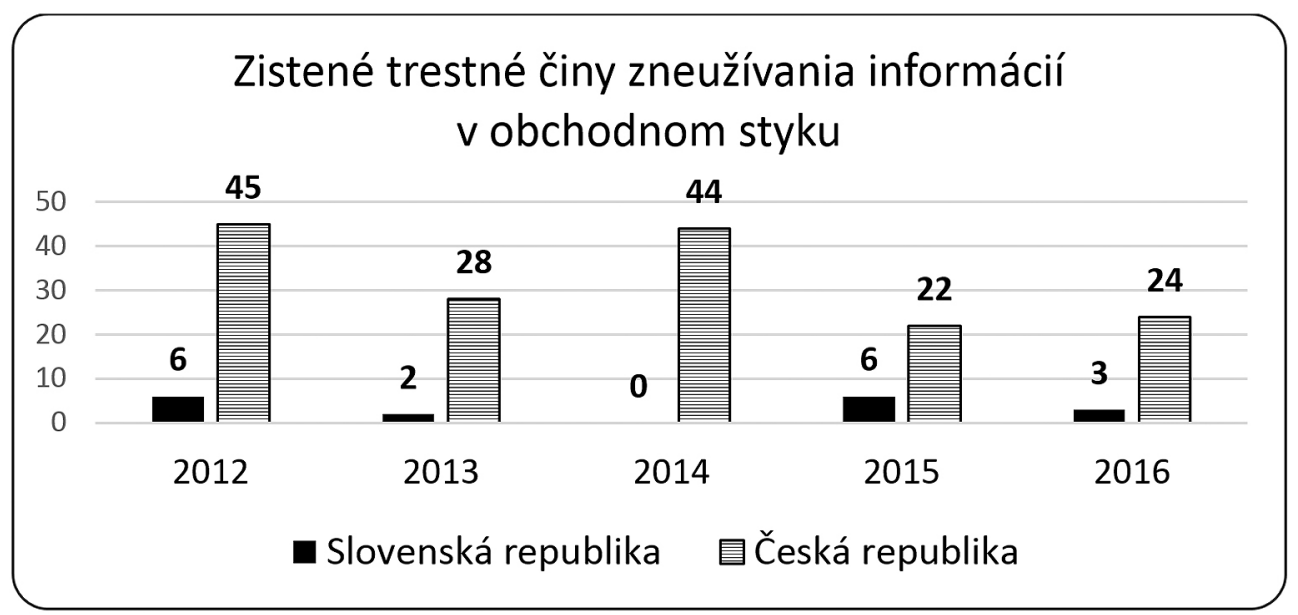

Zdroj: http://www.minv.sk a http://www.mvcr.cz

Je to zrejme ovplyvnené viacerými faktormi. Prvým faktorom je skutočnost', že na Slovensku riadne nefunguje kapitálový trh.

Slovenský kapitálový trh patrí v súčasnosti medzi najmenšie trhy v Európe. Kapitálový trh na Slovensku vznikol ako vedl'ajší produkt kupónovej privatizácie, a nie z potreby investorov a emitentov, ako je bežné v iných trhových ekonomikách. To do istej miery predznamenáva aj charakter jeho fungovania. Objem obchodov na Burze cenných papierov v Bratislave bol v porovnaní s inými krajinami vel’mi nízky. V súčasnosti akciový trh na Slovensku takmer neexistuje, viac ako 99 \% obchodov na Burze cenných papierov tvorí obchodovanie s dlhopismi. Obchody s akciami dosiahli v roku 2014 sumu 56 miliónov EUR. ${ }^{27}$ Slovenský kapitálový trh je jeden z najmenej funkčných spomedzi

27 Bližšie LOJSCHOVÁ, A. Kapitálový trh na Slovensku. Biatec, roč. 24, 2/2016, s. 14. 
krajín Európskej únie. Štúdia NewFinancial zarad’uje Slovensko na 29. miesto z 31 krajín Európy. ${ }^{28}$

Druhým problémom, je, že trestné činy súvisiace so zneužívaní finančného trhu je, že majú blanketový charakter. Znamená to, že Trestný zákon odkazuje na iné právne normy, ktoré sú obsiahnuté $\mathrm{v}$ iných právnych predpisoch. Táto skutočnost' st’ažuje orientáciu v danej oblasti jednak na strane podnikatel'ov ale aj orgánov činných v trestnom konaní. Pre aplikáciu príslušných ustanovení Trestného zákona je nevyhnutné poznat' aj mimo trestnú úpravu napr. Obchodný zákonník, živnostenský zákon, daňové zákony a pod. Pri trestných činoch súvisiacich so zneužívaním finančného trhu je situácia ešte zložitejšia. Právna úprava proti zneužívaniu trhu je upravená v nariadení o zneužívaní trhu, ${ }^{29}$ čo má za následok, že nariadenie je priamo uplatnitel'né, bez potreby transpozície do vnútroštátneho právneho poriadku. To by malo zabezpečit’ jednotné podmienky aplikácie v členských štátoch tým, že sa zabráni rozdielnosti vnútroštátnych požiadaviek v dôsledku transpozície smernice.

28 Decoding capital markets union: report on the potential growth in European capital markets, May 2015, Unlocking Capital Markets, by William Wright \& Laurence Bax [online], [cit. 2017-01-18], available http:/ / newfinancial.eu/decoding-capital-markets-union-report-on-the-potential-growth-in-european-capital-markets/

29 Nariadenie Európskeho parlamentu a Rady (EÚ) č. 596/2014 zo 16. apríla 2014 o zneužívaní trhu (nariadenie o zneužívaní trhu), Ú. v. EÚ L 173, 12. 6. 2014, s. 1-61. 